University of Montana

ScholarWorks at University of Montana

$1-28-2013$

\title{
Dynamically downscaled winter precipitation over complex terrain of the Central Rockies of Western Montana, USA
}

\author{
Nicholas Loren Silverman \\ The University of Montana \\ Marco P. Maneta \\ University of Montana - Missoula, marco.maneta@umontana.edu \\ S.-H. Chen \\ University of California - Davis \\ Joel T. Harper \\ University of Montana - Missoula, joel.harper@mso.umt.edu
}

Follow this and additional works at: https://scholarworks.umt.edu/geosci_pubs

Part of the Geology Commons

Let us know how access to this document benefits you.

\section{Recommended Citation}

Silverman, N. L., M. P. Maneta, S.-H. Chen, and J. T. Harper (2013), Dynamically downscaled winter precipitation over complex terrain of the Central Rockies of Western Montana, USA, Water Resour. Res., 49, doi:10.1029/2012WR012874.

This Article is brought to you for free and open access by the Geosciences at ScholarWorks at University of Montana. It has been accepted for inclusion in Geosciences Faculty Publications by an authorized administrator of ScholarWorks at University of Montana. For more information, please contact scholarworks@mso.umt.edu. 


\title{
Dynamically downscaled winter precipitation over complex terrain of the Central Rockies of Western Montana, USA
}

\author{
N. L. Silverman, ${ }^{1}$ M. P. Maneta, ${ }^{1}$ S.-H. Chen, ${ }^{2}$ and J. T. Harper ${ }^{1}$ \\ Received 28 August 2012; revised 2 November 2012; accepted 9 December 2012; published 28 January 2013.
}

[1] We evaluate the results of dynamically downscaled winter precipitation over Western Montana using the weather research and forecasting (WRF) model through comparison with estimates from the observationally based parameter-elevation regressions on independent slopes model (PRISM). Seven years (six winters) from 2000 to 2006 are simulated at $4 \mathrm{~km}$ resolution to assess the similarities and differences between the two models as well as the implications for hydrologic modeling. Inherent biases in both approaches are apparent, highlighting the difficulty in climate model validation. Results show general agreement between the two models in the spatial distribution of winter precipitation. A principal component analysis shows similar spatial patterns between models in the leading six components suggesting that the main processes that drive the spatial distribution of precipitation were properly captured. The first component explains almost $70 \%$ of total variance, and the first three components explain more than $85 \%$ in both data sets. The largest differences between the two data sets exist in areas at high elevation and upstream of the continental divide where observations are sparse. In these areas, WRF consistently predicts higher amounts of precipitation and larger interannual variability than PRISM. We suggest that these results are realistic for impingement of moist air masses on topography and, if correct, could have significant implications in flood forecasting, water resource management, and climate change studies.

Citation: Silverman, N. L., M. P. Maneta, S.-H. Chen, and J. T. Harper (2013), Dynamically downscaled winter precipitation over complex terrain of the Central Rockies of Western Montana, USA, Water Resour. Res., 49, doi:10.1029/2012WR012874.

\section{Introduction}

[2] Winter precipitation stored as snow plays a crucial role in providing spring and summer water resources across the western United States. Soil moisture and groundwater are essential to hydrologic and ecologic systems during the spring growing season, whereas late summer river discharge is critical for irrigation, energy production, and urban water use. Hydrologic regions driven by snowmelt are especially sensitive to winter precipitation magnitude and spatial distribution in headwater catchments [Gomi et al., 2002]. In this regard, the Central Rockies of Western Montana are of particular interest. This area acts as the "Crown of the Continent" by which precipitation that falls within the region may end up as part of either the Arctic, Atlantic, or Pacific Oceans. Major river systems such as the Columbia, Missouri, and Saskatchewan are all impacted by the weather and climate of Western Montana. Therefore, an accurate assessment of the volume of water input within

\footnotetext{
${ }^{1}$ Department of Geosciences, University of Montana, Missoula, Montana, USA.

${ }^{2}$ Department of Land, Air and Water Resources, University of California, Davis, California, USA.

Corresponding author: N. L. Silverman, Department of Geosciences, University of Montana, 32 Campus Drive 1296, Missoula, MT 59812, USA. (nicholas.silverman@umontana.edu)

C2012. American Geophysical Union. All Rights Reserved. 0043-1397/13/2012WR012874
}

this region and how it is distributed is critical to understanding its ecohydrologic and economic function. Furthermore, it is also an important region when evaluating the impacts of climate change across the western United States and North America.

[3] Hydrologic models used for flood forecasting, water resource management, and regional climate change studies often rely on winter precipitation derived from permanent observational networks such as SNOTEL (SNOpack TELemetry), remote automated weather stations, and National Oceanic and Atmospheric Administration Cooperative Observer Program [Garen et al., 1994; Clark et al., 2006; Marks et al., 1999]. These networks are usually sparse in mountain regions and may be insufficient to characterize precipitation across complex terrain and at high elevations [Serreze et al., 2003, 2005; Bales et al., 2006]. They are, furthermore, subject to measurement errors, such as snow undercatch, as well as local biases caused by rough topography and microclimate [Groisman et al., 1996; Jeton et al., 2005; Rice et al., 2011]. With high relief, steep slopes, and numerous valleys and parallel ranges, Western Montana potentially experiences exacerbated levels of each of these issues.

[4] An alternative to the use of ground observations to estimate winter precipitation is to dynamically downscale global climate model (GCM) simulations using a regional climate model (RCM). RCMs can provide both high spatial and temporal resolution (subkilometer and hourly, respectively) in areas with complex topography and little or no 
observational data. This makes them ideal in evaluating climate at the watershed scale and in areas with sparse ground observations. Dynamical RCMs use physically based mass and energy transfer equations between the atmosphere and land surface as well as advective flux terms from outside the model domain to estimate precipitation. The governing equations are solved with appropriate boundary and initial conditions provided by a GCM and therefore do not require direct information from ground observations. In this study, we adopt the weather research and forecasting (WRF) model [Skamarock and Klemp, 2008] as the RCM with boundary conditions from the National Center for Environmental Prediction Global Forecasting System Final (NCEP GFS-FNL) data set to estimate winter precipitation. Although dynamical models, such as WRF, avoid many of the issues surrounding observational data, they exhibit biases stemming from the physics schemes, downscaling methodology, and parameter estimations [Caldwell et al., 2009]. These biases, as well as the associated uncertainties, should be evaluated before use as input to hydrologic models.

[5] Here, we compare the results of our WRF simulations with the parameter-elevation regressions on independent slopes model (PRISM) [Daly et al., 1994, 2008]. PRISM is one of the most comprehensive and widely used observationally based climate data sets. Its estimated precipitation and temperature fields are commonly used in hydrologic studies of watersheds with complex topography [Mote et al., 2005; Nijssen et al., 1997; Vogel et al., 1999]. PRISM uses a statistically derived linear lapse rate to interpolate between observations that are weighted according to a variety of environmental and station location factors. Such factors include station clustering, distance, and elevation; slope aspect and gradient; coastal proximity; effective terrain height; atmospheric layering; and topographic position [Daly et al., 2008]. By incorporating these factors into the weighting scheme, PRISM is able to embrace some of the nonlinear physics that are otherwise lacking in standard statistically based models. Although it uses advanced algorithms, the accuracy of PRISM is still highly dependent on both observational quantity and quality, which makes it susceptible to sparse data in high mountain ranges. Nevertheless, PRISM is widely used as forcing data in hydrologic studies, since it is perhaps the best observationally based method available.

[6] In this paper, we analyze the spatial distribution of winter precipitation over the Central Rockies of Western Montana as simulated by WRF and PRISM. We do not attempt to validate WRF with PRISM but instead simply compare the results of the two models and discuss the similarities, differences, and biases in the context of hydrologic modeling. We use the winter seasons from 2000 to 2006 and notice overall similarities between the two models but some significant differences at high elevations on mountain ranges upstream of the continental divide. We suggest that the WRF model's simulations in poorly sampled areas, where PRISM is expected to underperform, appear more realistic based on the previous studies on advection of moist air masses over complex terrain [Hayes et al., 2002; Rasmussen et al., 2001; Kim, 1997] and that practitioners should be cautious when using statistical and observationally based models as a validation benchmark to dynamical models. Furthermore, the differences in the two models raise a particular concern when using observation-based winter precipitation estimates to force hydrologic models, because there is potential for large underprediction at high elevations in complex terrain. This may have significant consequences in the assessment of available water in mountain regions and, therefore, have implications for flood forecasting, water resource management, and the assessment of the hydrologic impacts of climate change.

\section{Methods}

\subsection{Model}

[7] WRF is a compressible, nonhydrostatic weather model using terrain-following coordinates. The governing equations are written in flux form, which conserves mass and dry entropy. The Advance Research WRF model version 3.2 [Skamarock and Klemp, 2008] is used for climate downscaling. Three domains with two way nesting are configured for all simulations. Two way nesting is used to upscale the terrain and cloud effects to coarser domains to provide more accurate boundary conditions to higher-resolution domains in complex topographic areas. This method has been shown to lead to overall more accurate results [Wang et al., 2012; Harris and Durran, 2010]. Figure 2 illustrates the location of the three domains. The NCEP GFS-FNL Operational Global Analysis is used to drive the WRF downscaling simulations. The FNL has a spatial resolution of $1^{\circ} \times 1^{\circ}$ and a temporal resolution of $6 \mathrm{~h}$. The data were produced using the Global Data Assimilation System to continuously assimilate observations from the Global Telecommunications System, satellites, and other sources into model outputs. This study uses the results from domain 3 .

[8] The model was configured with the six class microphysics scheme [Hong and Lim, 2006], the Monin-Obukhov with Carlson-Boland surface layer physics [Monin, 1954], the Yonsei University planetary boundary [Noh et al., 2003], the Noah land surface model [Chen, 2001], and the KainFritsch scheme that was used for cumulus parameterization in domains 1 and 2 [Kain and Fritsch, 1990; Kain, 1993]. We did not use a cumulus scheme for the inner domain (domain 3 ), because the $4 \mathrm{~km}$ resolution can resolve convection explicitly [Kain, 2004]. These schemes were chosen based on similar studies performed over California and Nevada during the same time period and using the identical data set for boundary conditions [Pan et al., 2010].

\subsection{Study Site}

[9] The study site domain is approximately $160,000 \mathrm{~km}^{2}$ with latitude ranging from around $44.7^{\circ} \mathrm{N}$ to $49^{\circ} \mathrm{N}$ and longitude from $110^{\circ} \mathrm{W}$ to $116^{\circ} \mathrm{W}$. Within the study site, there are several mountain ranges making up the larger range of the Central Rocky Mountains. This study focuses on the ranges west of the continental divide where terrain is most complex and precipitation is more abundant. This area of the state is drained predominantly by the Kootenai, Clark Fork, and Flathead Rivers that contribute to the greater Columbia River and eventually the Pacific Ocean. The origins of these rivers lie within the high western slopes of the Central Rockies, and their flow magnitude and timing (along with the larger rivers they feed) are critical to the water resources of the Pacific Northwest. 

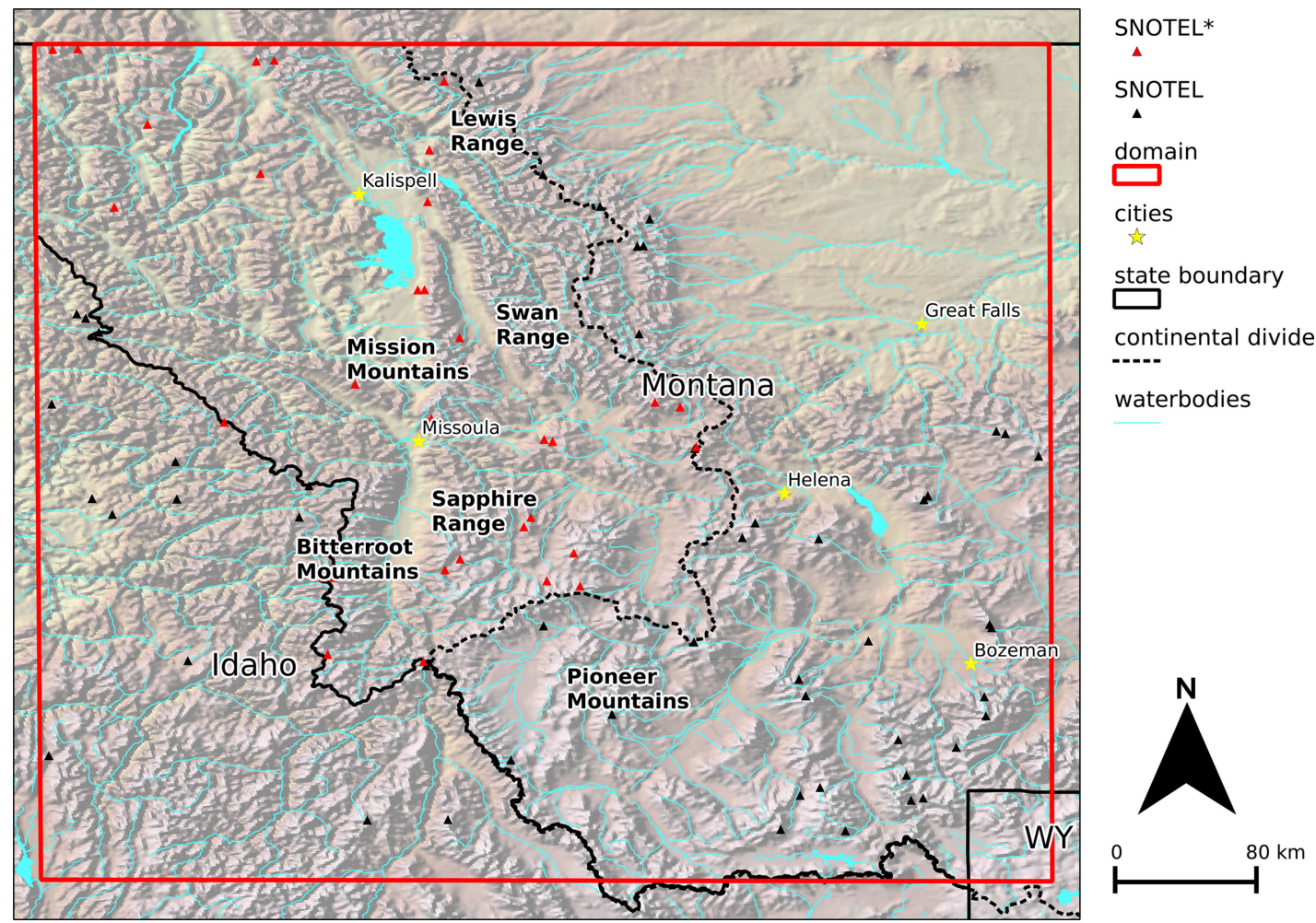

Figure 1. Study domain with major cities, mountain ranges, and SNOTEL stations labeled. Although statistics include the entire domain, many of the results are focused on the areas within Montana and west of the continental divide, as these areas are the most topographically complex and moisture rich. SNOTEL* are the stations within this area and used in the model comparisons.

[10] Montana elevations west of the divide vary from $600 \mathrm{~m}$ in the northwest corner of the state to over $3000 \mathrm{~m}$ on the peaks of the Bitterroot, Mission, and Lewis ranges (Figure 1). Many of the mountain ranges are oriented in the north-south direction with predominant climate patterns moving west-east. These climate patterns are primarily driven by Pacific coastal systems with occasional interruptions by continental air masses from the north and east. This gives rise to strong orographic uplifting over steep topographic gradients, as these systems move in from the relatively flat areas of eastern Washington and Oregon. This leads to large amounts of precipitation, which normally falls as snow at high elevations during winter months. Precipitation in this region is highly correlated with elevation. Areas adjacent to mountain ranges are generally wetter, with the exception of rain shadow effects on lee-side (eastern) slopes and valleys.

\subsection{Experimental Setup}

[11] A single WRF simulation was run for the years 2000-2006. Winter precipitation was extracted from this data set and evaluated over the complex terrain of Western Montana. During this time period, both El Niño and La Niña events took place. In 2000, a weaker La Niña winter marked cooler and wetter conditions, whereas, in 2002, 2004, and 2006, El Niño effects created warmer winter conditions. Winter months are defined as December through March, because these are the months in which precipitation falls mainly as snow. For the dynamical downscaling, we used three domains with resolutions of 36,12 , and $4 \mathrm{~km}$, respectively (Figure 2). The model was integrated with a time step of $180 \mathrm{~s}$ for domain 1. Monthly statistics computed for this study were based on hourly output from the model.

[12] The PRISM data set was regridded to match WRF using simple inverse distance weighting. PRISM data are gridded interpolated values at $4 \mathrm{~km}$ resolution from observations using a network of weather stations. These observations are weighted using environmental and station location factors. PRISM data are averaged to give monthly accumulated precipitation, which determined the temporal resolution of the dynamical downscaling for accurate comparisons between the models.

[13] Thirty-two SNOTEL stations from within Montana and west of the continental divide (SNOTEL* in Figure 1) were compared with overlapping grid cells from both models. These stations were chosen, because they include areas of complex terrain and high precipitation rates. One station (Noisy Basin) was thrown out as an outlier due to leverage on regression statistics. Since precise SNOTEL locations are not given and grid-cell-to-point comparisons have a range of issues [Molotch and Bales, 2005], this outlier could be related to a number of factors, which will be discussed in more detail in the subsequent section.

\section{Results}

[14] Topography determined, to a large extent, the spatial distribution of precipitation (Figure 3). Dominant patterns of orographic lifting, lee-side rain shadows, and 


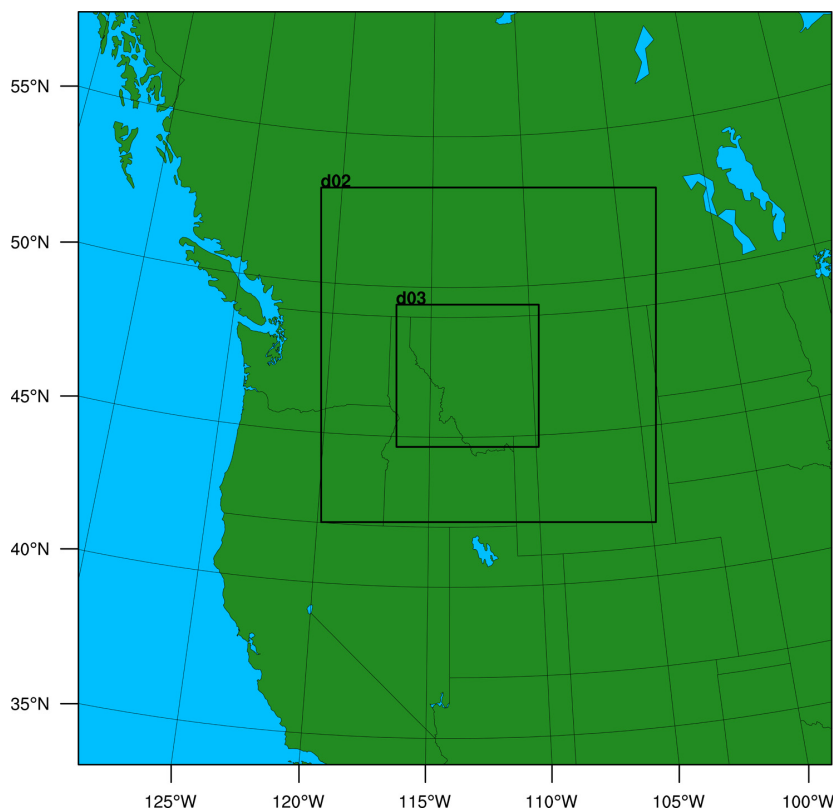

Figure 2. Nested domains used in the WRF dynamic downscaling. The outer domain has a resolution of $36 \mathrm{~km}$, the middle domain " $\mathrm{d} 02$ " has a resolution of $12 \mathrm{~km}$, and the inner domain " $\mathrm{d} 03$ " has a resolution of $4 \mathrm{~km}$ and is the boundary of our study site.

mountain blocking effects were generally captured by both models. Maximum precipitation occurs along the peaks of the western ranges, and minima are located east of the continental divide. There are also local precipitation minima in valleys east of high-elevation ranges.

[15] General statistics for winter precipitation for the WRF (domain 3) and PRISM models are illustrated in Table 1. Overall, WRF predicts consistently higher values of winter precipitation with the largest discrepancy in the maximum values $(137.446 \mathrm{~mm} / \mathrm{month})$. Differences in the overall interannual standard deviation across the domain are less consistent. WRF has a slightly lower minimum and mean standard deviation and a higher maximum. These results are most likely related to topographic effects that are discussed below.

[16] A comparison of each model with a selected group of SNOTEL stations show that WRF tends to overestimate precipitation at the SNOTEL sites and PRISM underestimates precipitation at the SNOTEL sites (Figures $4 \mathrm{a}$ and $4 \mathrm{~b})$. WRF has a bias and root-mean-square error (RMSE) of 34.64 and $61.37 \mathrm{~mm} / \mathrm{month}$, respectively. PRISM has a bias and RMSE of -7.54 and $26.16 \mathrm{~mm} / \mathrm{month}$, respectively. There are some inherent issues with comparing SNOTEL point observations with $4 \mathrm{~km}$ grid cells. In complex terrain, grid-cell elevation, aspect, and slope are averaged across the landscape, whereas SNOTEL observations are of a single point. Spatial distribution of winter precipitation across a $4 \mathrm{~km}$ area is known to vary greatly, and, therefore, direct comparison can be misleading [Molotch and Bales, 2005]. In addition, SNOTEL precipitation gauges have been shown to exhibit large undercatch biases [Groisman et al., 1996; Serreze et al., 1999]. Furthermore, these same observations are used by PRISM in its statistical (a) WRF Average Monthly Winter Precip. (mm)

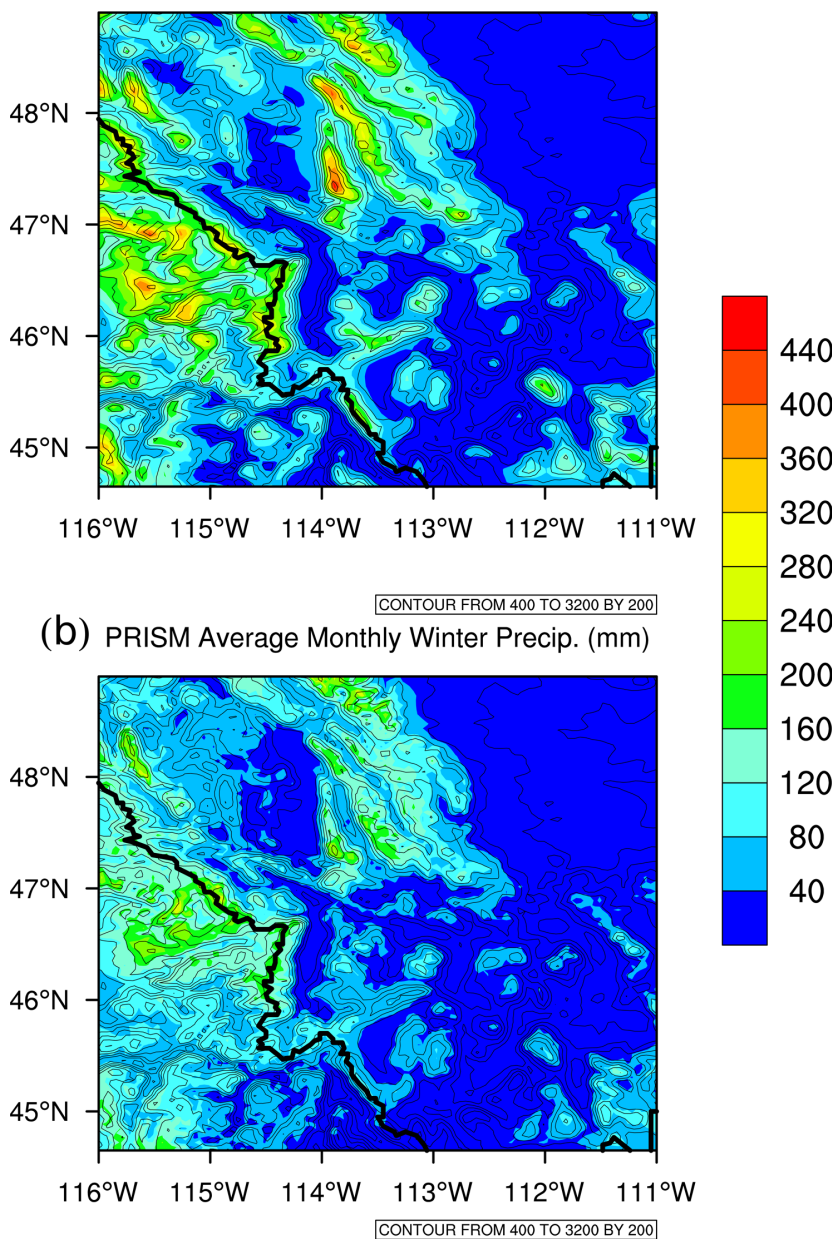

Figure 3. Average monthly winter precipitation (mm) estimates from the (a) WRF model and (b) PRISM. Topographic contours are overlaid in both maps, and the dark black line is the Idaho-Montana state boundary.

interpolation. This presents a best case scenario for the PRISM model, whereas WRF's predictions are completely independent of SNOTEL observations. Nonetheless, these results are similar to those throughout this study: WRF generally predicts higher amounts of precipitation than PRISM, and both models may have associated biases that exacerbate their differences.

Table 1. Standard WRF and PRISM Statistics Calculated for All Grid Cells Within the Domain

\begin{tabular}{lccc}
\hline & $\begin{array}{c}\text { WRF } \\
(\mathrm{mm} / \mathrm{month})\end{array}$ & $\begin{array}{c}\text { PRISM } \\
(\mathrm{mm} / \mathrm{month})\end{array}$ & $\begin{array}{c}\text { Difference } \\
\text { (WRF - PRISM) }\end{array}$ \\
\hline Minimum & 7.14 & 4.48 & 2.66 \\
Mean & 76.37 & 55.49 & 20.88 \\
Maximum & 454.04 & 316.60 & 137.45 \\
Standard deviation & 0.68 & 1.07 & -0.39 \\
$\quad$ minimum & 15.06 & 16.58 & -1.52 \\
$\quad \begin{array}{l}\text { Standard deviation } \\
\quad \text { mean }\end{array}$ & & 84.22 & 7.32 \\
$\quad \begin{array}{l}\text { Standard deviation } \\
\quad \text { maximum }\end{array}$ & 91.53 & &
\end{tabular}




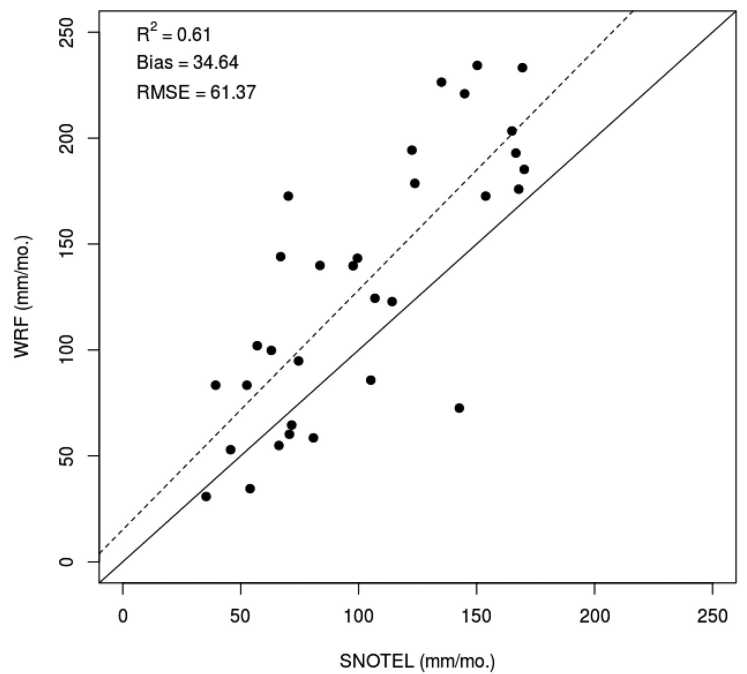

(a)

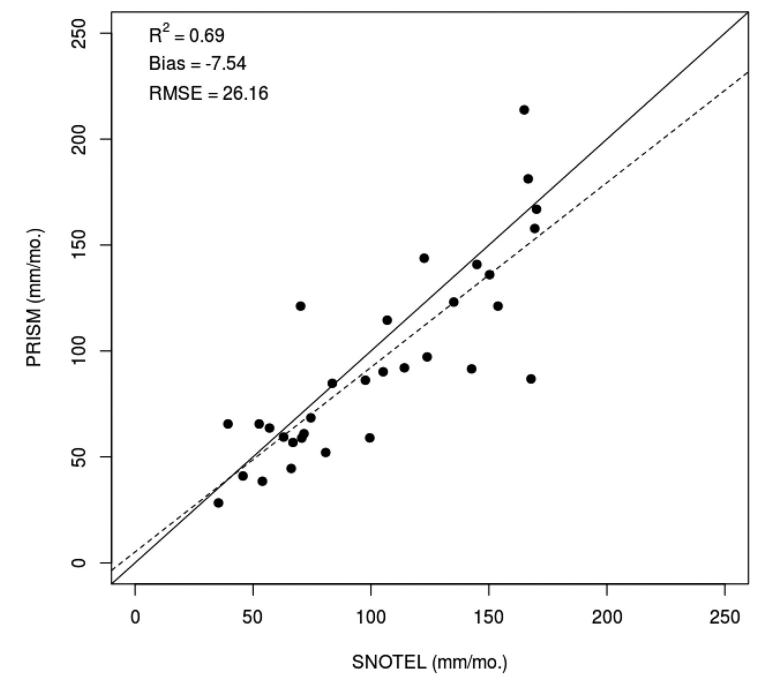

(b)

Figure 4. Thirty-two SNOTEL observations from the areas of complex terrain and west of the continental divide (SNOTEL* stations in Figure 1) are compared with the models. The solid line represents the idealized 1:1 relationship, and the dashed line represents the best fit linear regression. Statistical comparisons between the model and observations are provided. (a) Comparison with the WRF model. Here, predicted values tend to overestimate SNOTEL observations. (b) Comparison with the PRISM model. Overall, PRISM tends to underestimate SNOTEL observations. These data present a best case scenario for PRISM, because the SNOTEL observations themselves are used in the model.

[17] We performed a standard principal component analysis for both PRISM and WRF to further investigate the spatial patterns of precipitation over the region. The spatial loadings for the first six components are shown in Figures 5 and 6 . The first component alone accounts for $69.5 \%$ and $68.7 \%$ of the total variance of the WRF and PRISM data sets, respectively. The first three components explain more than $85 \%$ in both data sets. The first two components have high loadings of the same sign across the domain, indicating high spatial correlation of the precipitation process, which may be associated with frontal events sweeping the entire region. The smaller modes (components 3 and above) are still relevant, since they absorb more than $10 \%$ of the variability and show spatial patterns clustered around high topographic regions that may be interpreted as local storm events induced by high topography. The spatial patterns presented by the first six leading components were remarkably similar in both data sets, suggesting that the main processes that drive the spatial distribution of precipitation were properly captured. As expected, divergence between WRF and PRISM increased in the smaller modes of variability.

[18] Although the overall spatial distribution of the precipitation was consistent between WRF and PRISM, the magnitude of the precipitation was vastly different, as revealed in the difference map (Figure 7). WRF consistently estimated higher amounts of precipitation on highelevation peaks and slightly lower amounts of precipitation in the valleys when compared to PRISM. In some places, such as the Mission Mountains (approximately $47.3^{\circ} \mathrm{N}$ and $\left.113.8^{\circ} \mathrm{W}\right)$, WRF estimated twice as much precipitation (440 mm/month versus $240 \mathrm{~mm} /$ month). This is because WRF tended to sustain steeper precipitation lapse rates at high elevation.
[19] The distribution of precipitation versus elevation for both WRF and PRISM confirms that WRF consistently estimated higher precipitation at high elevation and that the disagreement between the two models increases with elevation (Figure 7). In both models, the largest amount of precipitation was seen on the peaks between 1300 and $2200 \mathrm{~m}$ west of the continental divide. Many of the highest peaks (2400 $\mathrm{m}$ and greater), however, are located east of the continental divide where precipitation is reduced because of rain shadow effects.

[20] In both data sets, high-elevation areas that have large precipitation amounts are also the areas that had the highest interannual variability and therefore introduce the largest uncertainty in the assessment of total volume of precipitation over the region (Figure 8). WRF generally shows larger variability in higher-elevation regions, and PRISM has slightly higher variability at low elevation. High-elevation areas $(>1800 \mathrm{~m})$ account for approximately $50 \%$ of the total study region and account for an even larger share of the total precipitation input. Unfortunately, these regions are also the ones that are the most undersampled by permanent monitoring networks.

[21] The longitudinal distribution of precipitation in the region is elucidated by five cross sections cut through the main ranges and valleys (Figure 9). Overall, in low-elevation regions, both models agreed in their estimation of precipitation. The biggest discrepancies were observed at the first significant topographic barrier on the western (leeside) slopes of the region (Figure 9a). When storms reach steep terrain, both models increased precipitation at similar lapse rates as topography steepened but diverged at moderate and high elevation. PRISM's precipitation lapse rate "flattened" at about $1200 \mathrm{~m}$ and a value of $100 \mathrm{~mm} / \mathrm{month}$ before the first peak (e.g., west of $14.25^{\circ} \mathrm{W}$ ), whereas 

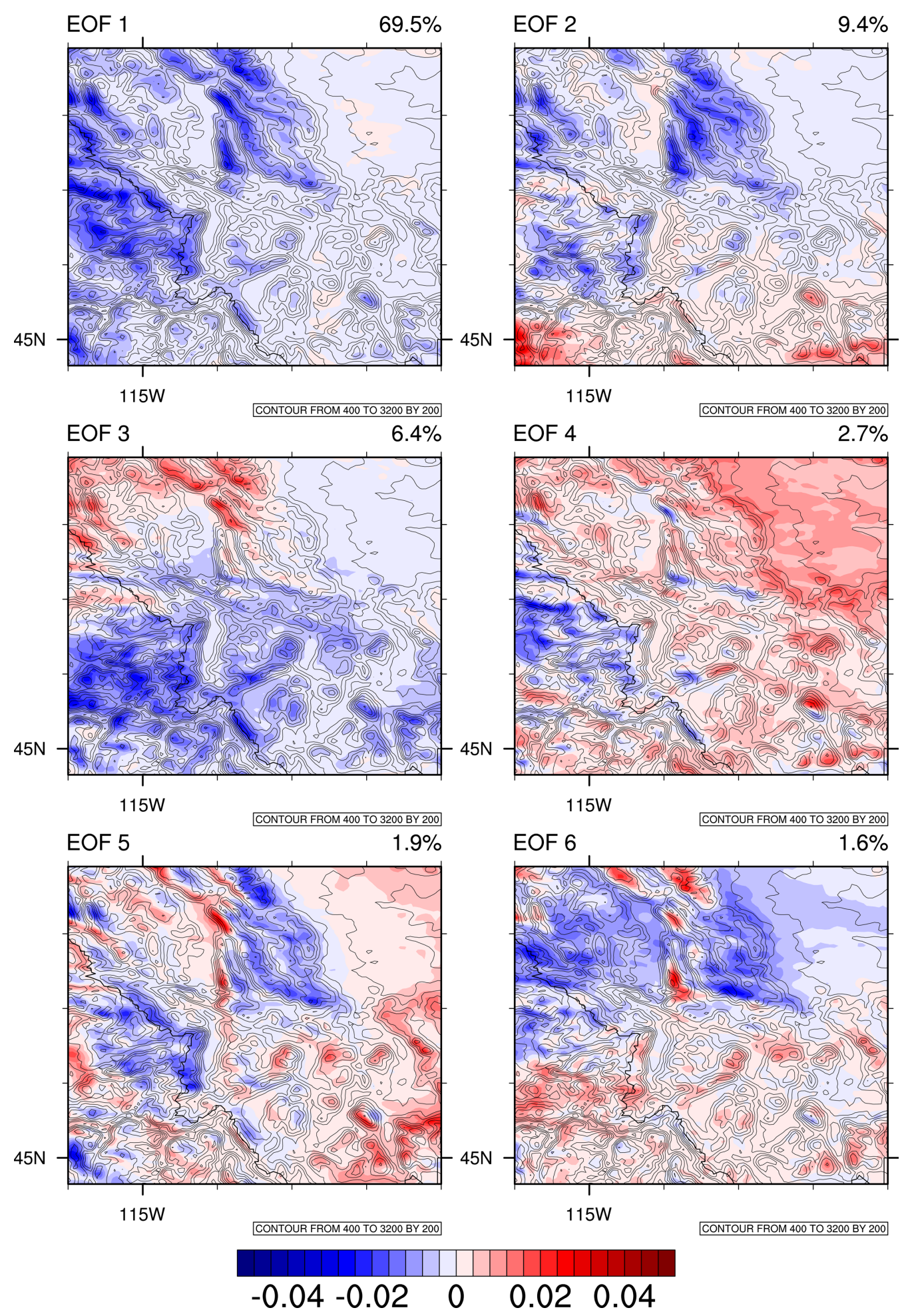

Figure 5. Spatial loadings for the first six principal components of the WRF monthly winter precipitation. The first component accounts for $69.5 \%$ of the variance and is most likely related to large frontal events with high spatial correlation. The smaller modes are more closely tied to local events.

WRF's estimate of precipitation continued increasing until it peaked at more than twice this for the top of the mountain. The recession trend on the lee side of the first (westernmost) peak is similar for both models. Figures $9 \mathrm{~b}$ and $9 \mathrm{c}$ present two isolated peaks located near the longitudinal center of the domain. In this case, precipitation lapse trends were similar through the windward side of the mountain, but WRF estimated a sustained increase in precipitation past the peak and over the lee side of the mountain. Although there are no data available to confirm enhanced 

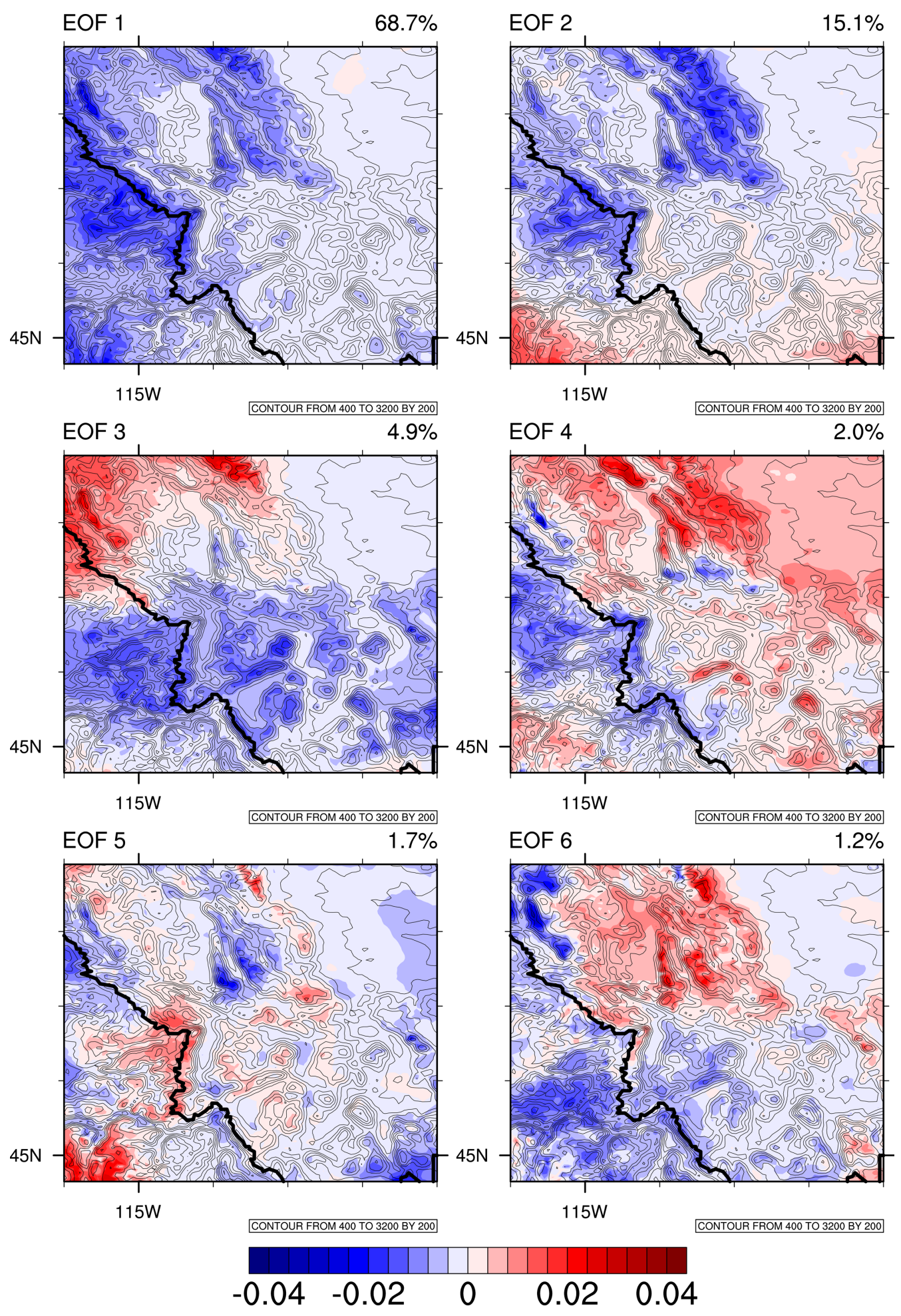

Figure 6. Spatial loadings for the first six principal components of the PRISM monthly winter precipitation. The first component accounts for $68.7 \%$ of the variance and is most likely related to large frontal events with high spatial correlation. The smaller modes are more closely tied to local events. The first four components are very similar to the first four components from the WRF model.

precipitation or snow on the leeward side of the mountain, this is often the case in isolated peaks when strong updrafts on the windward side preclude precipitation until the storm reaches the lee side [Colle et al., 2000; Houze, 2012]. In other cases, topography ramps up more gradually, such as the transition from the Salmon River valley through the Clearwater and Bitterroot Mountains (Figure 9d, longitude $\left.116^{\circ} \mathrm{W}-114^{\circ} \mathrm{W}\right)$. In this case, WRF still estimated higher 


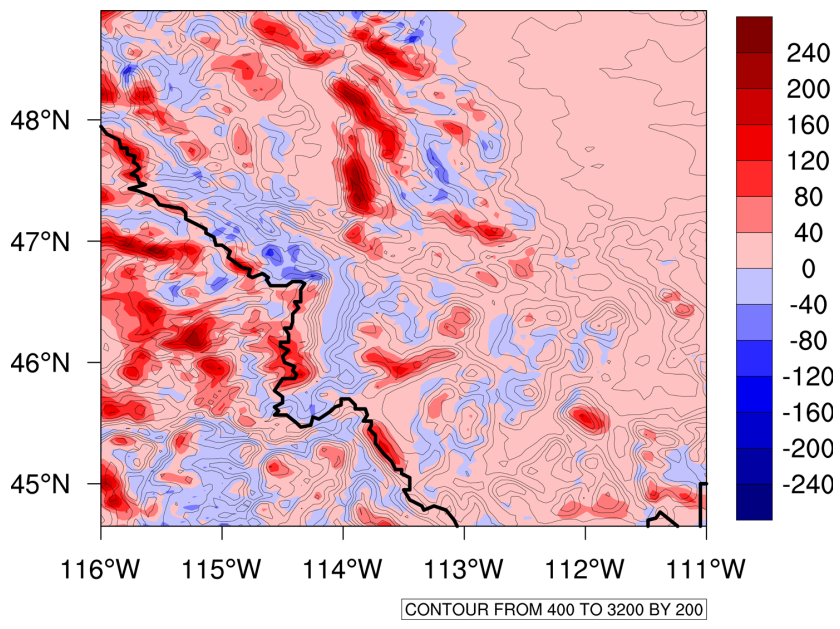

Figure 7. A map WRF values minus PRISM values. The largest differences are in the high elevations. Topographic contours are overlaid. The dark black line is the IdahoMontana state boundary.

precipitation than PRISM over these ranges until it reaches the Bitterroot valley at about $114^{\circ} \mathrm{W}$. Elevations further east in the Sapphire and Pintlar mountains, even though higher, are in the rain shadow of the Bitterroot mountains and receive less precipitation. Agreement between WRF and PRISM is better in this region.

[22] In general, WRF and PRISM agreed well in the estimation of precipitation in the regions east of the first topographic barrier once WRF released moisture carried by the air mass. As discussed below, this may be interpreted as an overestimation of the effect of topography or an overestimation of the moisture content in the air mass by WRF but should also be considered under the perspective of an underestimation of the precipitation by PRISM, because its algorithm relies on the measurements that are usually taken at low and moderate elevations.

[23] Agreement between models is relatively good in the southern mountain regions within the domain. The southernmost cross section runs through a region of higher elevation (Figure 9e). WRF and PRISM predict similarly through the entire cross section. Most likely, this is caused by relatively lower precipitation across the region and no clear individual topographic barrier that forces the uplift of moist air. It is worth noting that, for all cross sections, the models were in good agreement in many places where a SNOTEL station exists, whereas model divergences often occurred in regions where PRISM's estimation was far from the SNOTEL locations.

\section{Discussion}

[24] Winter weather in Western Montana is driven by the west-east pass of frontal storms originated in the Pacific Northwest, regional lee-side cyclones [Serreze et al., 1999], and other local storms that are associated with topography and restricted to smaller areas. Frontal passage is highly influenced by the Pacific North American (PNA) pattern [Cayan, 1996], with wetter winters associated with negative PNA anomalies. Both local storms and frontal passage determine the spatial distribution of precipitation over the region. Because frontal events impact the entire region, we expect precipitation inputs from these storms to be highly spatially autocorrelated. On the other hand, storms associated with topography are local in nature and may remain undetected or poorly characterized in areas without ground sensors. This has implications in the accuracy of observationally based models as well as validation of dynamically and physically based models.

[25] In this study, we find the largest discrepancies between models are over areas where no observational data are available. This makes the validation of the models very challenging. In general, both models showed a strong correlation between precipitation and elevation; rain shadowing effects from larger mountain ranges were also captured by both models. Furthermore, the dominant spatial patterns as identified in the leading empirical orthogonal function mode analysis also agreed, which provides confidence in the ability of both WRF and PRISM to capture the largescale patterns of precipitation. The more fundamental differences between the two models are greatest near

(a) WRF Winter Standard Dev. (mm)

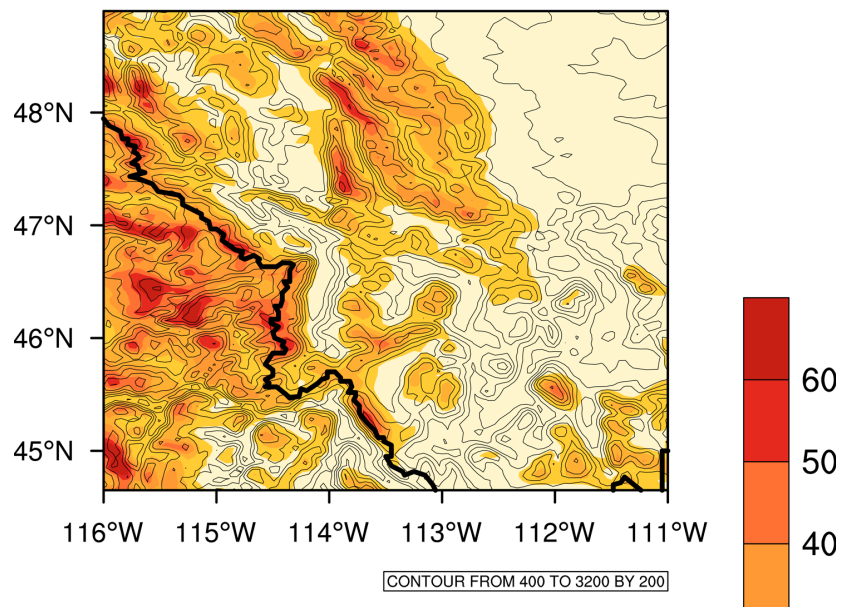

(b) PRISM Winter Standard Dev (mm)

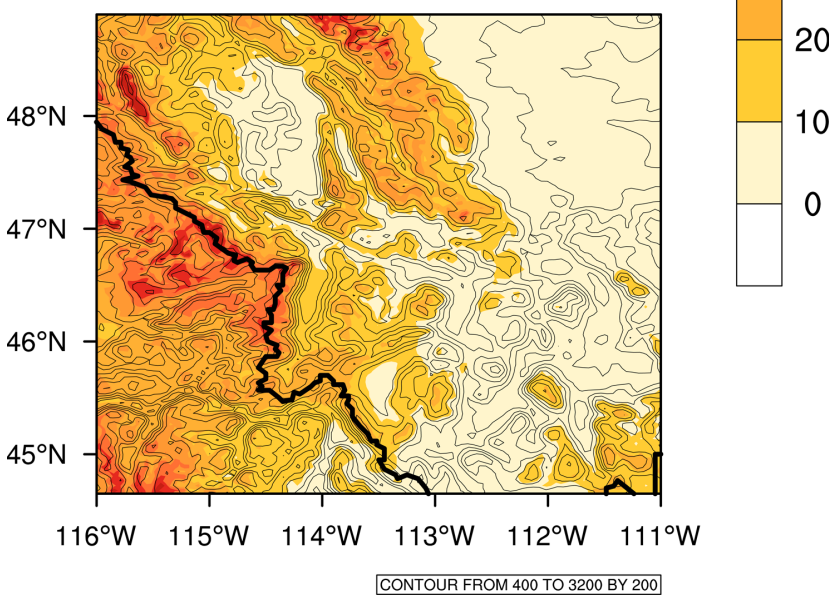

Figure 8. Interannual standard deviation map of (a) WRF and (b) PRISM. Topographic contours are overlaid, and the dark black line represents the Idaho-Montana state boundary. The highest standard deviation is generally in the areas of high elevation. 
(a)

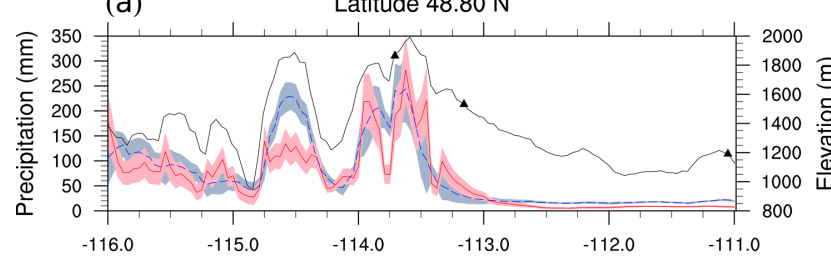

(b)
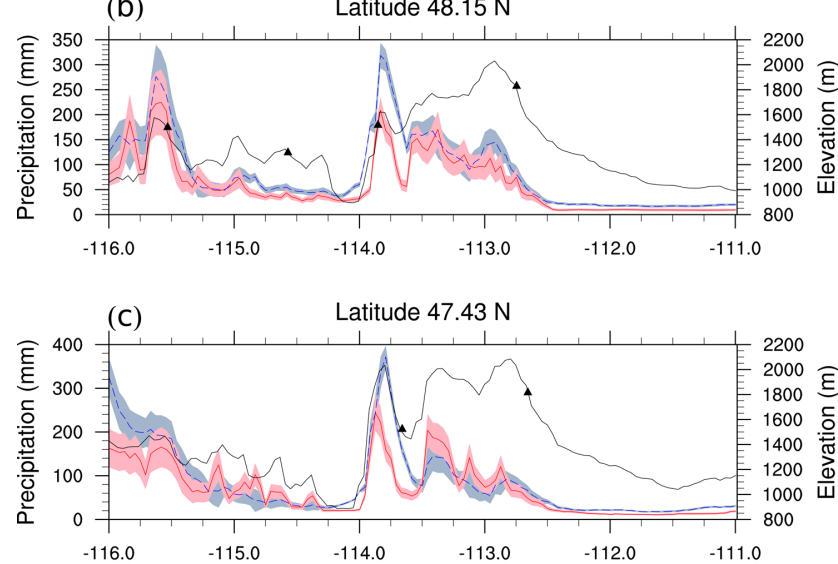

(d)

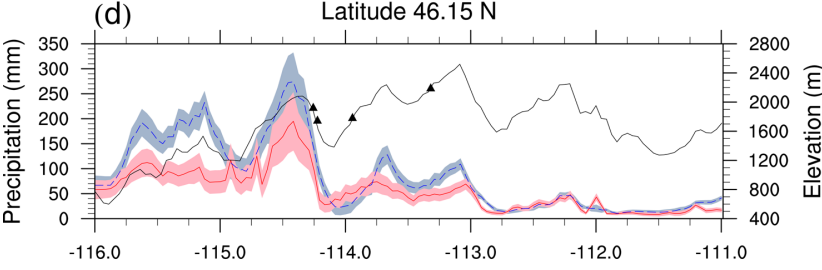

(e)

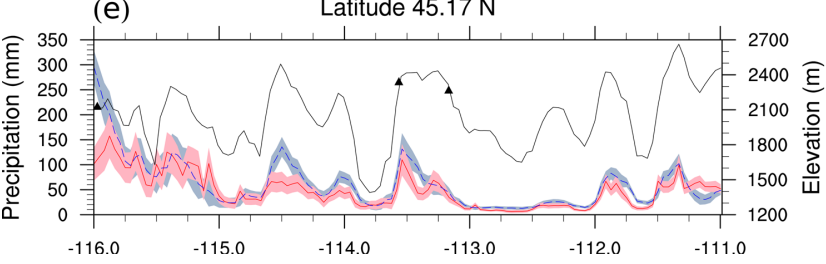

Digital Elevation Model

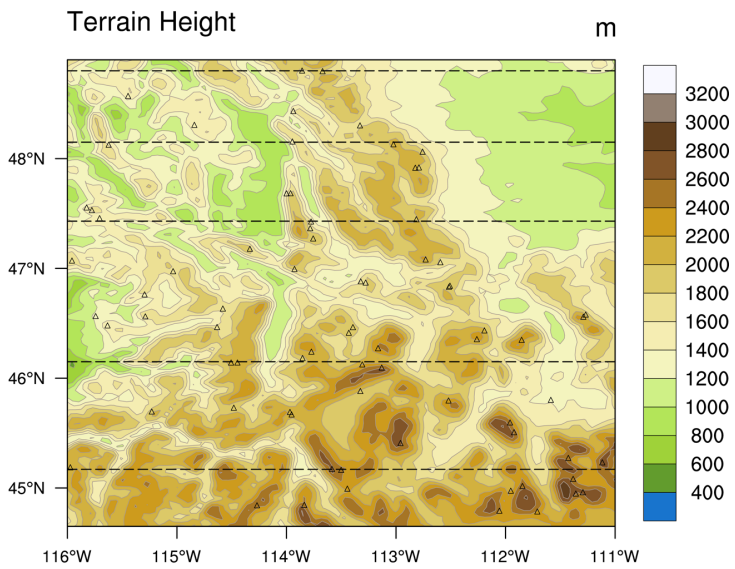

\section{Legend:}

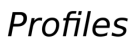

DEM

Terrain

WRF

Profiles

SNOTEL

PRISM

Figure 9. (a-e) Five cross sections taken north-south through the study domain. Both WRF (blue) and PRISM (red) winter precipitation are illustrated with their respective standard deviation. The black line is topographic elevation. Cross sections are located on the DEM, and triangles mark the SNOTEL stations on both the cross sections and DEM map. SNOTEL stations located within $4 \mathrm{~km}$ north or south of the cross section were included. SNOTEL station locations on the cross sections are approximate.

mountain tops where the amount of precipitation and interannual variability are the highest. WRF generally predicts a larger amount of precipitation at higher elevations than PRISM; previous studies typically attribute this difference to an overestimation by WRF [Wang et al., 2009; Caldwell et al., 2009; Hahn and Mass, 2009]. Most of these studies, however, were either focused on different geographic regions (mainly coastal) or performed at much lower spatial resolutions. For this reason, a complete explanation must include the possibility of both, overestimating by WRF and/or underestimating by PRISM.

\subsection{WRF Wet Bias}

[26] Previous dynamical downscaling studies have shown that positive precipitation bias in WRF may be either inherited from the driving GCM data or contributed by WRF itself due to the physics parameterizations [Caldwell et al., 2009]. Any biases in the GCM data are partially corrected through the assimilation of observations in the FNL analysis. Although this may reduce any exaggerated moisture fluxes within the GCM, it does not completely eliminate the possibility of precipitation overestimation, which could then be transferred to the WRF model [Janowiak et al., 1998].

[27] Precipitation bias within WRF could come from a number of sources. Some studies have shown that precipitation bias increases with higher resolution [Leung et al., 2003]. This may be attributed to sensitivity in physics parameterizations and dependence on spatial resolution. At $4 \mathrm{~km}$ resolution, Mass et al. [2002] showed that numerical forecast models have the highest positive precipitation bias when compared to model results with resolutions of 36 and 
$12 \mathrm{~km}$. They also note, however, that the overprediction is largely dependent on the intensity of the rainfall and that high intensities from the $4 \mathrm{~km}$ resolution were the most skillful. A similar finding was recently reported by Jin and Wen [2012]. The overestimation of precipitation could be because most of the physics parameterizations in mesoscale models were originally developed for a coarser resolution. At greater resolutions, there is less topographic smoothing, and higher elevations will be preserved, increasing orographic effects and making it possible for higher precipitation amounts to exist. Also, higher precipitation and temperature fluxes due to better represented topography improves the simulation of the snowpack, which feeds back into the atmospheric system, altering (typically reducing) latent heat exchanges from the land surface to the atmosphere [Jin and Wen, 2012].

[28] Another suggested cause of WRF wet bias is the land use characteristic map. The WRF default, used in this study, is the U.S. Geological Survey Global Land Cover Characteristics data set, compiled in 1992-1993. There is a more current data set available in WRF, the International Geosphere-Biosphere Programme-Moderate Resolution Imaging Spectrometer (MODIS) land cover database that was compiled with data from 2001 to 2002 . A visual inspection of these two land use maps (not shown) suggests that there are only minor differences within our study domain, and recent studies have suggested that the effect of a more accurate land use map is limited. Pohl [2011] showed that, if anything, using the newer MODIS data set slightly increases precipitation and that a rainfall bias is more likely to be related to model physics than the prescribed land use.

[29] The WRF model physics are complex, and determining optimal parameters for specific regions is still an active area of research. Most of the configurations used in this study are recommended values or based on previous simulations at similar resolutions and geographic regions [Gutmann et al., 2011; Pan et al., 2010]. One of the most critical parameterization schemes in WRF is the cloud convection. We use the Kain-Fritsch scheme [Kain and Fritsch, 1990; Kain, 1993] to estimate atmospheric mass flux. Although most of the schemes available in WRF have similar skill in precipitation estimation, the Kain-Fritsch scheme tends to predict spatial distribution particularly well and is less sensitive to grid-cell resolution. It has, however, been shown to overpredict lower intensity rain events as well as precipitation in mountain regions [Wang and Seaman, 1997; Caldwell et al., 2009]. Caldwell et al. [2009] show that the alternative schemes do not necessarily produce less moisture but simply distribute it differently, producing slightly less precipitation (approximately 5\%) in mountain regions at the expense of increasing precipitation in regions upstream. Determining whether using alternative physics schemes would produce a more accurate description of the precipitation distribution is challenging. Most likely, the potential wet bias in the model is from a combination of sources, including boundary conditions, the choice of physics and dynamic parameters, and characterization of the land surface. Optimizing parameters to improve the representation of precipitation is challenging, because the observational data itself may have its own associated biases.

\subsection{PRISM Dry Bias}

[30] The majority of the studies that have identified precipitation bias in WRF use reconstructed precipitation fields from PRISM or other statistical models [Caldwell et al., 2009; Pan et al., 2010; Qian et al., 2009]. Herein lies the difficulty in quantifying the true bias of WRF. Mass balance studies of PRISM-produced climate have shown the potential for substantial underestimation of precipitation in headwater catchments [Westrick et al., 2002]. Underestimates in statistical models may come from a variety of sources: systematic measurement error, station location bias, data sparseness, and complex physical interactions at high elevation to name a few.

[31] Systematic measurement error is well documented in many hydrologic and atmospheric studies [Bogdanova et al., 2002; Groisman et al., 1996; Xia and Xu, 2007]. Precipitation gauges tend to measure less precipitation than actual amounts due to wind-blowing effects, evaporation before measurement, and wetting losses on the walls of the gauge. Although many of these effects can be minor, the accumulated monthly sum can be upward of $2 \%-10 \%$ depending on location, average temperatures, and rain intensity [Groisman et al., 1996; Serreze et al., 1999]. These errors can be corrected, but the majority of the station data used in observationally based models have not been rigorously checked for quality or accuracy [Daly et al., 1994]. The overall differences, however, between the two models cannot be explained by measurement error alone.

[32] Precipitation gauge locations are often in the areas that are easy to access and, on average, at relatively low elevations compared the surrounding landscape. This leaves large areas atop mountains with little to no observational data [Rice et al., 2011; Molotch, 2009]. In a study within Western Montana, Gillan et al. [2010] found that more than $25 \%$ of the snow water equivalent (SWE) accumulated above the highest observation station. They further note that more than $70 \%$ of SWE is accumulated above the average elevation of the surrounding stations. Most statistical methods compensate for this by including information on elevation, slope, orientation, and effective height relative to station location as covariate factors that help extrapolate precipitation values. PRISM is a complete statistical model in that it incorporates all of the abovementioned parameters into its weighting scheme to determine a local linear precipitation lapse rate [Daly et al., 2008]. This method has proven to be very accurate in regions with ample observational data, linear lapse rates, and stable air flow but may introduce errors in regions with complex precipitation lapse rates such as mountain regions [Minder et al., 2010]. Jeton et al. [2005] found that, in the areas of poorly resolved elevation, PRISM underestimated precipitation up to $60 \%$ in comparison to SNOTEL station data. Some of this error may be attributed to the inherent difficulty in comparing point data with grid-cell averages, but Jeton et al. [2005] point out that there is a general pattern of PRISM underestimation in the areas of higher mean annual precipitation.

[33] Furthermore, statistical models (including PRISM) do not use information about wind direction and speed, airflow dynamics, or cloud properties. In complex terrain, these physical parameters can lead to strong nonlinearity in precipitation-elevation relationships. The amount of precipitation along windward slopes is related to the magnitude 
of the horizontal flow impinging on a mountain barrier. This flow can act as an enhancement to precipitation on windward slopes and can vary in both space and time due to numerous climatic factors. If low-level fronts are blocked by mountain barriers, orographic effects can take place further downstream as upper level flows ascend the blocked air. This creates precipitation at lower levels and a more gradual lapse rate. If there is no lower-level blockage, upslope flow does not occur until interacting with the windward mountain slope [Neiman et al., 2002]. This increases lapse rate and enhances mountaintop precipitation. To compensate for this, statistical methods use a temporal average, but this may lead to errors in precipitation magnitude and spatial distribution in complex terrain [Houze, 2012].

\subsection{Spatial Distribution}

[34] As noted previously, the overall spatial distribution is similar between PRISM and WRF. Precipitation trends are dominated by orographic effects where terrain creates uplift and precipitation increases with elevation. In both models, maximum precipitation occurs at high elevations and minimums in the flat valleys and plains east of the continental divide. There are, however, large differences between WRF and PRISM in the precipitation response to orographic effects on the western (windward) slopes of the Central Rockies. In mountain ranges east of this initial rise, WRF and PRISM have more comparable estimates.

[35] Several possible reasons may account for the inconsistencies of west-to-east rainfall patterns between WRF and PRISM. There are two main air masses that affect the Central Rockies: the maritime polar air and the continental polar air. The maritime polar air mass originates from the Pacific and is characterized by cool moist air that comes in from the west and rises up, over, and across the Central Rockies. When this moisture laden air gets advected over the western slopes of local mountain ranges it can lead to large amounts of precipitation and a decrease in humidity. In contrast, the continental polar air mass originates from the north and is characterized by cold and dry air. This air mass is common east of the continental divide and contains less moisture and consequently produces less precipitation [Kittel et al., 2002]. The two distinctly different air masses along with the large topographic relief of the Central Rockies create many complex physical relationships among the wind, humidity, and terrain. In addition, the locations of peak rainfall can be shifted between statistical and dynamical model results over high, narrow mountain ranges due to cloud developing time and advection. Smaller mountains take less time for a storm to pass over, and, therefore, rainfall maximum can be shifted to the peak or lee side of the mountain. Dynamical models can simulate this trend, whereas observationally based models may have difficulties where data are sparse.

[36] Moisture influx from frontal passage originating in the Pacific has been shown to be strongly correlated with precipitation over the western United States; the steep terrain of the Rockies is efficient at extracting this moisture from orographic forcings, which makes humidity a key component of weather prediction [Kim, 1997]. Previous models have used only humidity, dominant wind direction, and topographic orientation to successfully predict precipitation patterns in the northwest United States [Hayes et al.,
2002; Rasmussen et al., 2001]. By this notion and the greater understanding of the characteristics of the regional air masses, it is anticipated that the western slopes of our domain would receive significantly more precipitation than the more interior slopes [Barros and Lettenmaier, 1994]. WRF appears to more consistently agree with this trend, whereas PRISM estimates seem to more closely follow pure elevational trends (Figure 9).

[37] The discrepancy in the two models could be a seasonal effect. Annual relationships between elevation and precipitation have been found to differ greatly from seasonal relationships in the regions of complex terrain [Hanson, 2001; Hayes et al., 2002; Singh and Kumar, 1997]. In a study using long-term precipitation records over an experimental watershed in western Idaho, Hanson [2001] found that winter storms produced approximately five times more precipitation at the higher elevations than at the low elevations and that precipitation increase with elevation was much less during summer months than during the winter months. This particular study location, while outside of our domain, is very similar in longitude to our study domain and located on the western flanks of the Central Rockies. Since we focus only on winter precipitation and PRISM uses annual climatic trends to weight station observations [Daly et al., 2008], PRISM may be dampening the winter precipitation lapse rates in areas upstream of the continental divide. For example, in summer months, precipitation is more uniformly distributed across the landscape; this leads to a stronger correlation between similarly oriented adjacent mountain ranges than what might exist in the winter. This may explain why PRISM does not consistently estimate the large peak of precipitation on the western flanks of our domain. It should also be noted that although the discrepancy between the two models is generally largest in the most western locations, these are also areas with largest variation, which makes the difference in the two models less significant.

\subsection{Hydrologic Implications}

[38] Regional hydrologic models used in climate change studies [Liang et al., 1994; Tague and Band, 2004; Oleson et al., 2010] are dependent on the output from climate models. Many of these models use data derived from PRISM or WRF as forcings; this makes their differences (and biases) all the more important to understand. Our results show that, over much of Western Montana, both PRISM and WRF agree in their estimates of winter precipitation but at high elevations, especially west of the continental divide, their estimates diverge considerably. When using these models at a regional scale (e.g., for aid in developing management strategies), these differences may lead to large discrepancies, as the forcings (and uncertainties) propagate into hydrologic models.

[39] In some cases, where precipitation is shifted between PRISM and WRF, mass balance may be altered between two adjacent watersheds. This effect is noticeable in Figure 9b where WRF predicts a much larger amount of precipitation on the leeward slopes of the Mission Mountains (approximately $114^{\circ} \mathrm{W}$ ). In this area, the precipitation that falls on the leeward slopes directs water into the Hungry Horse Reservoir and through the $172 \mathrm{~m}$ tall Hungry Horse Dam. This dam is the third tallest within the Columbia River watershed and is a key component in regulating 
power, recreation, and flooding in the Pacific Northwest. This shift in precipitation may be the result of wind advection in WRF that is not directly accounted for in statistical models. Similar results have been seen in other WRF comparison studies in the Rocky Mountains [Gutmann et al., 2011].

[40] Precipitation at high elevations is important, because it falls mainly as snow in the Central Rockies and will most likely continue to fall as snow even under climate change scenarios [McCabe and Clark, 2005]. Therefore, misrepresenting high-elevation snowpack can greatly affect snowmelt timing and magnitude predictions [Gillan et al., 2010; McCabe and Clark, 2005]. Furthermore, this misrepresentation can feedback into snowmelt predictions from the alteration of depth, albedo, and slope aspect [Luce et al., 1998]. Snowmelt timing and magnitude are the key components to the water resources of the western United States, and quantifying their effects is imperative to future planning and management strategy development. Hydrologic models used for these purposes often use discharge measurements to calibrate regional parameters. If snowpack and melt are misrepresented in the input, parameterization of these models can lead to inaccurate future predictions.

\section{Conclusion}

[41] In this comparison study of predicted winter precipitation in complex terrain of the Central Rockies in Western Montana, we found that both physics-based dynamical downscaling (WRF) and observationally based interpolation (PRISM) methods of regional climate modeling agree overall across the domain. There are, however, certain areas within the region where differences are large and important. Specifically, in the areas of high elevation and west of the continental divide, WRF tends to predict higher amounts of precipitation than PRISM. Moreover, the locations of peak rainfall from WRF are often shifted downstream toward the mountain summit or lee side in high, narrow mountainous regions. Variance structure is similar within the domain where WRF has higher interannual variance than PRISM at high elevations. Although we emphasize that, with a study period of only 6 years, strong conclusions on interannual variability should not be made.

[42] At last, the differences between WRF and PRISM may be significant when using these predictions as forcings for hydrologic models. Studies have shown that modelderived precipitation may be more accurate than observations [Serreze et al., 2005]. Therefore, it is possible that Western Montana is, indeed, receiving more precipitation at high elevations than our observational data suggest, and this precipitation may play a major role in mitigating some of the effects of climate change on rivers and water resources.

[43] Acknowledgments. This work has been supported by grants from the Montana Water Resources Association, the Montana Space Grant Consortium/NASA EPSCoR, and the United States Environmental Protection Agency.

\section{References}

Bales, R., N. Molotch, T. Painter, M. Dettinger, R. Rice, and J. Dozier (2006), Mountain hydrology of the western United States, Water Resour. Res., 42, W08432, doi:10.1029/2005WR004387.
Barros, A., and D. Lettenmaier (1994), Dynamic modelling of orographically induced precipitation, Rev. Geophys., 32(3), 265-284.

Bogdanova, E., B. Ilyin, I. Dragomilova, V. Main, and G. Observatory (2002), Application of a comprehensive bias-correction model to precipitation measured at Russian North Pole drifting stations, J. Hydrometeorol., 3, 700-713.

Caldwell, P., H. Chin, D. Bader, and G. Bala (2009), Evaluation of a WRF dynamical downscaling simulation over California, Clim. Change, 95(34), 499-521, doi:10.1007/s10584-009-9583-5.

Cayan, D. (1996), Interannual climate variability and snowpack in the western United States, J. Clim., 9, 928-948.

Chen, F. (2001), Coupling an advanced land surface-hydrology model with the Penn State-NCAR MM5 modeling system. Part I: Model implementation and sensitivity, Mon. Weather Rev., 129, 569-585.

Clark, M. P., A. G. Slater, A. P. Barrett, L. E. Hay, G. J. McCabe, B. Rajagopalan, and G. H. Leavesley (2006), Assimilation of snow covered area information into hydrologic and land-surface models, Adv. Water Resour., 29(8), 1209-1221, doi:10.1016/j.advwatres.2005.10.001.

Colle, B., C. Mass, and K. Westrick (2000), MM5 precipitation verification over the Pacific Northwest during the 1997 to 1999 cool seasons, Weather Forecast., 15, 730-744.

Daly, C., R. Neilson, and D. Phillips (1994), A statistical-topographic model for mapping climatological precipitation over mountainous terrain, J. Appl. Meteorol., 33(2), 140-158.

Daly, C., M. Halbleib, J. I. Smith, W. P. Gibson, M. K. Doggett, G. H. Taylor, J. Curtis, and P. A. Pasteris (2008), Physiographically sensitive mapping of climatological temperature and precipitation across the conterminous United States, Int. J. Climatol., 28(15), 2031-2064, doi:10.1002/joc1688.

Garen, D. C., G. L. Johnson, and C. L. Hanson (1994), Mean areal precipitation for daily hydrologic modeling in mountainous regions, Water Resour. Bull., 30(3), 481-491.

Gillan, B. J., J. T. Harper, and J. N. Moore (2010), Timing of present and future snowmelt from high elevations in northwest Montana, Water Resour. Res., 46, W01507, doi:10.1029/2009WR007861.

Gomi, T., R. Sidle, and J. Richardson (2002), Understanding processes and downstream linkages of headwater systems, BioScience, 52(10), 905916

Groisman, P. Y., D. R. Easterling, R. G. Quayle, V. S. Golubev, A. N. Krenke, and A. Y. Mikhailov (1996), Reducing biases in estimates of precipitation over the United States: Phase 3 adjustments, J. Geophys. Res., 101(D3), 7185-7195, doi:10.1029/95JD02600.

Gutmann, E., R. Rasmussen, C. Liu, K. Ikeda, D. Gochis, M. Clark, J. Dudhia, and G. Thompson (2011), A comparison of statistical and dynamical downscaling of winter precipitation over complex terrain, J. Clim., 25(1), 262-281, doi:10.1175/2011JCLI4109.1.

Hahn, R., and C. Mass (2009), The impact of positive-definite moisture advection and low-level moisture flux bias over orography, Mon. Weather Rev., 137(9), 3055-3071, doi:10.1175/2009MWR2873.1.

Hanson, C. L. (2001), Long-term precipitation database, Reynolds Creek Experimental Watershed, Idaho, United States, Water Resour. Res., 37(11), 2831-2834.

Harris, L., and D. Durran (2010), An idealized comparison of one-way and two-way grid nesting, Mon. Weather Rev., 138, 2174-2187.

Hayes, P., L. Rasmussen, and H. Conway (2002), Estimating precipitation in the central Cascades of Washington, J. Hydrometeorol., 3, 335-346.

Hong, S.-Y., and J.-O. Lim (2006), The WRF Single-Moment 6-Class Microphysics Scheme (WSM6), J. Korean Meteorol. Soc., 42(2), 129151.

Houze, R. (2012), Orographic effects on precipitating clouds, Rev. Geophys., 50, RG1001, doi:10.1029/2011RG000365.

Janowiak, J. J., A. Gruber, and C. C. Kondragunta (1998), A comparison of the NCEP-NCAR reanalysis precipitation and the GPCP rain gauge-satellite combined dataset with observational error considerations, J. Clim., 11, 2960-2979.

Jeton, A., S. Watkins, and T. Lopes (2005), Evaluation of precipitation estimates from PRISM for the 1961-90 and 1971-2000 data sets, Nevada.

Jin, J., and L. Wen (2012), Evaluation of snowmelt simulation in the Weather Research and Forecasting model, J. Geophys. Res., 117, D10110, 1-16, doi:10.1029/2011JD016980.

Kain, J. (1993), Convective parameterization for mesoscale models: The Kain-Fritsch scheme, Am. Meteorol. Soc.-Meteorol. Monogr., 24, 165170 . 


\section{SILVERMAN ET AL.: DOWNSCALED WINTER PRECIPITATION WESTERN MONTANA}

Kain, J., and J. Fritsch (1990), A one-dimensional entraining/detraining plume model and its application in convective parameterization, $J$. Atmos. Sci., 47, 2784-2802.

Kain, J. S. (2004), The Kain-Fritsch convective parameterization: An update, J. Appl. Meteorol., 43(1), 170-181.

Kim, J. (1997), Precipitation and snow budget over the southwestern United States during the 1994-1995 winter season in a mesoscale model, Water Resour. Res., 33(12), 2831-2839.

Kittel, T., P. Thornton, A. Royle, and T. Chase (2002), Climates of the Rocky Mountains: Historical and future patterns, in Rocky Mountain Futures: An Ecological Perspective, edited by J. Baron, chap. 4, p. 59, Island Press, Washington, D. C.

Leung, L., and Y. Qian (2003), The sensitivity of precipitation and snowpack simulations to model resolution via nesting in regions of complex terrain, J. Hydrometeorol., 4, 1025-1043.

Liang, X., D. Lettenmaier, E. F. Wood, and S. Burges (1994), A simple hydrologically based model of land surface water and energy fluxes for general circulation models, J. Geophys. Res., 99(D7), 14,415-14,428.

Luce, C. H., D. G. Tarboton, and K. R. Cooley (1998), The influence of the spatial distribution of snow on basin-averaged snowmelt, Hydrol. Processes, 12(10-11), 1671-1683.

Marks, D., J. Domingo, D. Susong, T. Link, and D. Garen (1999), A spatially distributed energy balance snowmelt model for application in mountain basins, Hydrol. Processes, 13, 1935-1959.

Mass, C., D. Ovens, and K. Westrick (2002), Does increasing horizontal resolution produce more skillful forecasts, Bull. Am. Meteorol. Soc., 83(3), pp. 407-430.

McCabe, G., and M. Clark (2005), Trends and variability in snowmelt runoff in the western United States, J. Hydrometeorol., 6, 476-482.

Minder, J. R. (2010), The sensitivity of mountain snowpack accumulation to climate warming, J. Clim., 23(10), 2634-2650, doi:10.1175/ 2009JCLI3263.1.

Molotch, N. P., and R. C. Bales (2005), Scaling snow observations from the point to the grid element: Implications for observation network design, Water Resour. Res., 41, W11421, doi:10.1029/2005WR004229.

Molotch, N. P. N. (2009), Reconstructing snow water equivalent in the Rio Grande headwaters using remotely sensed snow cover data and a spatially distributed snowmelt model, Hydrol. Processes, 23, 1076-1089, doi:10.1002/hyp.

Monin, A. (1954), Basic laws of turbulent mixing in the surface layer of the atmosphere, Trudy Geofiz. Inst. Acad. Nauk. S.S.S.R., 24, 163-187.

Mote, P., A. Hamlet, M. Clark, and D. Lettenmaier (2005), Declining mountain snowpack in western North America, Bull. Am. Meteorol. Soc., 86, 39-49, doi:10.1175/BAMS-86-1-39.

Neiman, P., F. Ralph, and A. White (2002), The statistical relationship between upslope flow and rainfall in California's coastal mountains: Observations during CALJET, Mon. Weather Rev., 130, 1468-1492.

Nijssen, B., D. P. Lettenmaier, X. Liang, S. W. Wetzel, and E. F. Wood (1997), Streamflow simulation for continental-scale river basins, Water Resour. Res., 33(4), 711-724.

Noh, Y., W. Cheon, and S. Hong (2003), Improvement of the K-profile model for the planetary boundary layer based on large eddy simulation data, Boundary Layer Meteorol., 107, 401-427.

Oleson, K. W., et al. (2010), Technical description of version 4.0 of the community land model (CLM), NCAR/TN-478+STR, UCAR, Boulder, Colo.
Pan, L.-L., S.-H. Chen, D. Cayan, M.-Y. Lin, Q. Hart, M.-H. Zhang, Y. Liu, and J. Wang (2010), Influences of climate change on California and $\mathrm{Ne}$ vada regions revealed by a high-resolution dynamical downscaling study, Clim. Dyn., 37(9-10), 2005-2020, doi:10.1007/s00382-010-0961-5.

Pohl, B. (2011), Testing WRF capability in simulating the atmospheric water cycle over Equatorial East Africa, Clim. Dyn., 37(7-8), 13571379, doi: 10.1007/s00382-011-1024-2.

Qian, Y., S. J. Ghan, and L. R. Leung (2009), Downscaling hydroclimatic changes over the western US based on CAM subgrid scheme and WRF regional climate simulations, Int. J. Climatol., 30, 675-693, doi:10.1002/joc. 1928 .

Rasmussen, L., H. Conway, and P. S. Hayes (2001), Estimating Olympic Peninsula precipitation from upper, J. Geophys. Res., 106(D2), 14931501.

Rice, R., R. C. Bales, T. H. Painter, and J. Dozier (2011), Snow water equivalent along elevation gradients in the Merced and Tuolumne River basins of the Sierra Nevada, Water Resour. Res., 47, W08515, doi:10.1029/2010WR009278.

Serreze, M., M. Clark, and R. Armstrong (1999), Characteristics of the western United States snowpack from snowpack telemetry (SNOTEL) data, Water Resour. Res., 35(7), 2145-2160.

Serreze, M., M. Clark, and B. Polar (2003), Monitoring precipitation over the arctic terrestrial drainage system: Data requirements, shortcomings, and applications of atmospheric reanalysis, J. Hydrometeorol., 4, 387407.

Serreze, M., A. Barrett, and F. Lo (2005), Northern high-latitude precipitation as depicted by atmospheric reanalyses and satellite retrievals, Mon. Weather Rev., 133, 3407-3430.

Singh, P., and N. Kumar (1997), Effect of orography on precipitation in the western Himalayan region, J. Hydrol., 199, 183-206.

Skamarock, W. C., and J. B. Klemp (2008), A time-split nonhydrostatic atmospheric model for weather research and forecasting applications, $J$. Comput. Phys., 227(7), 3465-3485, doi:10.1016/j.jcp.2007.01.037.

Tague, C. L., and L. E. Band (2004), RHESSys: Regional hydro-ecologic simulation system-An object-oriented approach to spatially distributed modeling of carbon, water, and nutrient cycling, Earth Interact., 8(19), $1-42$.

Vogel, R., I. Wilson, and C. Daly (1999), Regional regression models of annual streamflow for the United States, J. Irrig. Drain. Eng., 125(3), 148-157.

Wang, S., R. Gillies, E. Takle, and W. Gutowski (2009), Evaluation of precipitation in the intermountain region as simulated by the NARCCAP regional climate models, Geophys. Res. Lett., 36, L11704, doi:10.1029/ 2009GL037930.

Wang, S., E. Yu, and H. Wang (2012), A simulation study of a heavy rainfall process over the Yangtze River valley using the two-way nesting approach, Adv. Atmos. Sci., 29(4), 731-743, doi:10.1007/s00376-0121176-y.

Wang, W., and N. Seaman (1997), A comparison study of convective parameterization schemes in a mesoscale model, Mon. Weather Rev., $125,252-278$.

Westrick, K., P. Storck, and C. Mass (2002), Description and evaluation of a hydrometeorological forecast system for mountainous watersheds, Weather Forecast., 17, 250-262.

Xia, Y., and G. Xu (2007), Impacts of systematic precipitation bias on simulations of water and energy balances in northwest America, Adv. Atmos. Sci., 24, 739-749. 